\title{
Remedy Australia: because every human rights violation should be remedied
}

\author{
Olivia Ball
}

Any person whose rights or freedoms as herein recognised are violated shall have an effective remedy ...'

- International Covenant on Civil and Political Rights, art. 2(3)

In the 20 years the Institute of Commonwealth Studies has been teaching the MA in human rights, 40 individual complaints of human rights violations by Australia have been upheld by the UN treaty bodies. This places Australia fifth of all participating nations for adverse findings by the UN committees (behind South Korea, Jamaica, Belarus and Uruguay). ${ }^{1}$

Yet, even by the most generous assessment, Australia has implemented only 15 per cent of these quasi-judicial decisions. Some gross violations identified in individual communications, far from being remedied, continue unchecked. ${ }^{2}$

1 UN Office of the High Commissioner for Human Rights (2014), Statistical survey of individual complaints dealt with by the Human Rights Committee (Geneva: United Nations), available at http://www.ohchr.org/Documents/HRBodies/CCPR/ StatisticalSurvey.xls (accessed 23 Sept. 2015); UN Office of the High Commissioner for Human Rights (2014), Statistical survey of individual complaints dealt with by CERD (Geneva: United Nations), available at http://www.ohchr.org/Documents/ HRBodies/CERD/StatisticalSurvey.xls (accessed 23 Sept. 2015); UN Office of the High Commissioner for Human Rights (2015), Status of communications dealt with by CAT (Geneva: United Nations), available at http://www.ohchr.org/Documents/ HRBodies/CAT/StatisticalSurvey.xls (accessed 23 Sept. 2015).

2 The travaux préparatoires of the 2005 Basic Principles and Guidelines on the Right to a Remedy and Reparation for Victims of Gross Violations of International Human Rights Law and Serious Violations of International Humanitarian Law (the 'Van Boven Principles') include a non-exhaustive list of gross violations: 'genocide; slavery and slavery-like practices; summary or arbitrary executions; torture and cruel, inhuman or degrading treatment or punishment; enforced disappearance; arbitrary and prolonged detention; deportation or forcible transfer of population; and systematic discrimination, in particular based on race or gender.' (T. Van Boven, Study 
My doctoral research, which looked at the value of UN communications to the people who initiate them, may be the first systematic empirical study of authors' experience in dealing with the UN treaty bodies and the long-term outcomes of their cases. ${ }^{3}$ To summarise my findings:

- Exhausting domestic remedies is onerous and often costly. However, most authors of individual communications would have pursued domestic remedies even without the UN requirement to do so.

- Although the communications procedure is designed to be accessible without needing a lawyer, having a lawyer is a big help.

- Authors found the communications procedures and operation of the committees difficult to understand and to follow as their case progressed, and the committees difficult to contact. ${ }^{4}$

- UN communications take, on average, more than three years from start to finish. Such delays pose difficulties for authors, especially those (such as detainees and deportees) experiencing gross violations of their human rights while they await an outcome.

- Although Australia has rejected almost all the committees' final views, it has, in most instances, acted on 'interim views' from the committees. These requests, seeking urgent action where irreparable harm is imminent, have most commonly asked Australia not to deport an author while their communication is underway. For refugees, this may save lives.

concerning the right to restitution, compensation and rehabilitation for victims of gross violations of human rights and fundamental freedoms, UN Doc E/CN4/Sub2/1993/8 (1993), principle 1.) More than half of the individual communications upheld against Australia have concerned arbitrary detention, and some of their authors, notably authors of F.K.A.G. et al. v. Australia and M.M.M. et al. v. Australia, are still detained. See the UN Human Rights Committee (2014), General comment No. 35, Article 9 (Liberty and security of person), UN Doc. CCPR/C/GC/35 (16 December 2014) on what constitutes arbitrary detention.

3 In-depth interviews were conducted with 18 complainants or 'authors' of communications in which Australia was found to be in breach of its human rights treaty obligations - all those authors who could be found and who agreed to participate. Only 33 communications had been decided against Australia at that point (1994-2013), so over half of all successful authors were interviewed for this research. They commented on the risks, time, effort, expense and other costs involved in pursuing this form of remedy, relative to the outcomes achieved. See O. Ball (2013), All the Way to the UN: Is petitioning a UN human-rights treaty body worthwhile?, unpublished doctoral thesis, Monash Law School (Melbourne).

4 Indeed, the treaty bodies sometimes have difficulty contacting authors. Some authors had no idea they had won a human rights complaint at the UN - some had no memory of even lodging one - until a doctoral student sought to interview them about it. 
- A small number of authors suffered significant negative consequences connected with their communication, such as hate mail, death threats, debt, bankruptcy, loss of employment and declining health, as well as opportunity costs while occupied with their communication.

- However, no-one felt any pressure to withdraw their UN complaint - either from the Australian government or from third parties. The evidence suggests that it is generally safe for people to petition the UN committees without fear of reprisal within Australia. ${ }^{5}$

- As noted above, Australia's compliance with final views of the treaty bodies has been very poor. The great majority of authors has received no substantive remedy at all. ${ }^{6}$ Most people have great difficulty exerting effective pressure to obtain compliance with the UN's views on their case. The reasons for this vary, including relative poverty, language barriers, incarceration, mental illness, insecure migration status and, perhaps most significantly, lack of support from the human rights movement. ${ }^{7}$

- A very limited number of authors report positive outcomes - often unexpected or indirect - such as respect among their peers and a positive public profile contributing to their professional standing; or a sense of achievement and self-confidence in new-found abilities developed or revealed in the process of defending their rights. However, most authors interviewed reported no positive outcomes from their communication.

5 This may help explain the relatively high number of communications brought against Australia, along with the generally free access to information about communications procedures, the availability of pro bono lawyers willing to assist authors and the dominant language of Australia being a UN language. Add to this the lack of an interim stratum of a regional court of human rights in the AsiaPacific, and people who have exhausted all domestic remedies have nowhere to go but the UN. While the risk of reprisal within Australia is low, authors seeking asylum may be placed at greater risk in their country of origin if they are identified in final views and refouled. Published views have revealed not only asylum seekers' identity, but also details of their family and the basis of their refugee claim. Some authors, and apparently some of their representatives, are not aware they can request anonymity from the treaty bodies.

6 In a limited sense, the verdict of a court or tribunal as to whether a human rights violation has occurred is itself a remedy. But surely the ICCPR's promise of an effective remedy means more than this. It is helpful to distinguish mere procedural remedies provided by courts from the substantive remedies which ought to follow, in which action is taken to end the violation (cessation), repair harm done (reparations) and/or prevent further violations (non-repetition).

7 A notable exception is the Australian human rights lawyers and legal academics who have represented authors. Most, if not all, have done so pro bono, but few pursue implementation of treaty body views. 
One might expect bitterness. The surprise finding was that most authors regard their UN communication as having been worthwhile. Despite the negative consequences far outnumbering any positive outcomes, most people thought complaining to the UN had been worth it. The value to authors of vindication by one of the world's highest human rights authorities is not to be underestimated, especially as it comes after the long journey of exhausting domestic remedies and the discouragement of having 'lost' their case at every prior tribunal.

In short, victims value procedural remedies, even in the absence of substantive remedies. Which is not to say they don't want substantive remedies, but they do face formidable challenges in securing them.

The Australian experience suggests authors are more likely to obtain a substantive remedy if they are able to secure significant media coverage of their UN case; and if they have ongoing, organised support of some kind. In Australia at least, most UN communications receive very little media coverage. Without public attention on the violation, there will be no public pressure; and without pressure exerted on duty-holders, they may be unlikely to provide a remedy.

Thus there seemed to be a gap in civil society for an organisation dedicated to publicising UN communications as they arrive, monitoring the state's response to them, and exerting political pressure, where necessary, to ensure implementation of committee views. Nick Toonen and I founded such an organisation and called it Remedy Australia.

Nick Toonen is the author of the very first individual communication filed against Australia. Toonen v. Australia was 'a decision of historic proportions ... with wide-ranging implications for the human rights of millions of people'. 8 It was exceptional in many ways, not least because it was initiated by a human rights $\mathrm{NGO}$ as a form of strategic litigation, backed by a long advocacy campaign for equality and justice (see box).

Toonen remains unsurpassed as the high-water mark for successful implementation of committee views in Australia. It is no accident that it resulted in substantive remedies for $\mathrm{Mr}$ Toonen and all LGBTI Tasmanians. No other author has had the benefit of a dedicated and determined civil society campaign to capitalise on his UN win. In contrast, most authors of communications against Australia remain disempowered, isolated and without remedy. They disappear from view, along with their case. Human rights organisations have generally failed to support authors and to capitalise on these high-level, independent pronouncements on states' human rights performance.

8 N. Pillay (2011) 'UN Human Rights Chief highlights Australian sexuality case' video address, uploaded by the Australian High Commission for Human Rights on its YouTube channel (25 July 2011), available at http://www.youtube.com/ watch?v=NT5aBa-1bXs (accessed 17 Sept. 2015). 


\section{Toonen v. Australia (HRC, 1994)}

Nick Toonen was a gay Tasmanian in a state where consenting sex between adult men in private was still punishable by up to 25 years' jail. Mr Toonen alleged that this violated his right to privacy and that the only effective remedy would be repeal of the relevant provisions of the Tasmanian Criminal Code. The Australian Government agreed with $\mathrm{Mr}$ Toonen, noting that homosexuality had been decriminalised in all other Australian jurisdictions. The Tasmanian Government defended its laws, however, on public health and moral grounds.

The UN Human Rights Committee (HRC) found the laws were an arbitrary interference with $\mathrm{Mr}$ Toonen's right to privacy and that an effective remedy would require the repeal of those laws. It also established that the prohibition on discrimination on the basis of 'sex' found in ICCPR articles 2(1) and 26 includes sexual orientation. Australia enacted the Human Rights (Sexual Conduct) Act 1994 (Cth) to prohibit laws that arbitrarily interfere with the sexual conduct of adults in private. Tasmania subsequently amended its Criminal Code.

Meanwhile, pressure on the state to provide each successful author with an effective and enforceable remedy diminishes over time.

If the UN's individual communication procedures are to be of practical value in preventing and redressing human rights violations, many countries may benefit from systematic civil society monitoring of treaty body jurisprudence and follow-up activity to ensure implementation of committee views.

Remedy Australia maintains a comprehensive online database of successful Australian communications and advocates for implementation of the remedies recommended by the committees in their final views. We campaign for individual remedies only with the consent of the author and/or their lawyer. The treaty bodies usually recommend guarantees of non-repetition as well, often in the form of law or policy reform. Thus remedies are not only for the individual, but should achieve broader, systemic advances in human rights protection.

In our first year, we had a significant win with Horvath v. Australia (see box). Working with Ms Horvath's lawyers, we mobilised thousands of supporters in an on- and off-line campaign that secured her a public apology and ex gratia payment as compensation, setting a new standard for timely and good-faith responses to individual communications, a mere five months after the UN Human Rights Committee's final views. The Police Act has also been amended, but Ms Horvath's lawyers - a community legal centre specialising in police misconduct cases - are not satisfied it goes far enough, and thus the Horvath 


\section{Horvath v. Australia (HRC, 2014)}

During an unlawful police raid on her home, 21-year-old Corinna Horvath was thrown to the floor and punched repeatedly in the face by a policeman until she was unconscious and her nose broken. She required surgery for her injuries. The County Court found the police guilty of trespass, assault, unlawful arrest and false imprisonment, and awarded Ms Horvath compensation, but the police force denied liability and did not discipline or prosecute any of the police officers involved. Eighteen years after the assault, the HRC found that Ms Horvath's right to an effective remedy had been violated and recommended law reform and compensation.

Nystrom v. Australia (HRC, 2011)

Stefan Nystrom was born in Sweden and entered Australia as a baby only 27 days old. Mr Nystrom began hearing voices in childhood and has suffered psychiatric symptoms throughout his life. From the age of ten, he began offending, usually under the influence of alcohol, leading ultimately to terms in prison.

At the age of 30, seven years after his last offence, during which time he had been law-abiding, steadily employed and recovering from his alcoholism, Mr Nystrom's visa was cancelled on character grounds. An appeal to the Federal Court found him to be 'an absorbed member of the Australian community with no relevant ties elsewhere'. The Immigration Minister appealed successfully to the High Court, however, and in 2009 deported Mr Nystrom to Sweden. Mr Nystrom knows no-one in Sweden and, due to a learning disability, has little capacity to learn Swedish or integrate successfully. Known locally as 'the Australian', Mr Nystrom has spent years either homeless, in homeless shelters, in prison or in psychiatric care.

The HRC found Mr Nystrom's deportation constituted arbitrary interference with his right to family and (in a landmark ruling) his 'right to enter his own country', which is Australia, despite his not being an Australian citizen. Further, his expulsion was arbitrary - occurring so long after his offending. In the view of the HRC, he should be permitted and materially assisted to return to Australia. Australia has refused to allow $\mathrm{Mr}$ Nystrom back into Australia, but says it has made policy reforms to guard against repetition. 
case is only partially remedied and we continue to campaign for further law reform.

Conversely, in the case of Nystrom, Australia has acted to prevent repetition, but refuses to remedy the individual violation, which Remedy Australia regards as urgent, given the violation is ongoing and given Mr Nystrom's vulnerabilities and parlous existence (see box).

Finally, in addition to publicising committee views and advocating for individual and preventive remedies, Remedy Australia seeks to close the loop by feeding information back to the UN treaty bodies. Through direct contact with authors and their representatives and systematic monitoring, we provide the UN committees with independent, accurate and up-to-date information on any progress towards implementation of each of its views, complementing and supporting the treaty bodies' own efforts at follow-up.

We welcome the establishment of sister organisations around the world. Is there a need for a branch of Remedy where you are? 